\title{
Parasites of economically important bivalves from the southern coast of Bahia State, Brazil
}

\author{
Parasitos de bivalves de interesse econômico no Litoral Sul do Estado da Bahia, Brasil \\ Gabriela Calvi Zeidan ${ }^{1}$; Mariane dos Santos Aguiar Luz²; Guisla Boehs ${ }^{1,2 *}$
}

${ }^{1}$ Programa de Pós-graduação em Sistemas Aquáticos Tropicais, Universidade Estadual de Santa Cruz - UESC, Ilhéus, BA, Brasil

${ }^{2}$ Programa de Pós-graduação em Ciência Animal, Universidade Estadual de Santa Cruz - UESC, Ilhéus, BA, Brasil

Received June 23, 2012

Accepted October 16, 2012

\begin{abstract}
This study investigated the parasites of three commercially important bivalve species (Crassostrea rhizophorae, Mytella guyanensis and Lucina pectinata) from the southern coast of Bahia, Brazil. A total of 540 specimens were collected in August 2009 and February 2010, at three localities. The bivalve specimens were measured on their longest axis, opened, and macroscopically examined for the presence of parasites or signs of disease. They were then fixed in Davidson' solution and subjected to routine histological processing, with paraffin embedding and H\&E staining; next, the specimens were examined under a light microscope. No parasites were observed associated with L. pectinata. Rickettsialike organisms (RLOs), Sphenophrya sp. (Ciliophora), Nematopsis sp. (Apicomplexa), Urastoma sp. (Turbellaria) and Bucephalus sp. (Digenea) were observed in both C. rhizophorae and M. guyanensis, as well as Ancistrocoma sp. (Ciliophora) and Tylocephalum sp. (Cestoda) in the former. A high prevalence of Nematopsis sp. was seen, but caused no apparent damage to the host. Bucephalus sp. caused the destruction of tissues, with castration, but showed low prevalence. The other parasites occurred in low prevalence and intensity, without causing significant damage.
\end{abstract}

Keywords: Crassostrea rhizophorae, Lucina pectinata, Mytella guyanensis, pathogens, bivalves, parasites.

\section{Resumo}

Neste estudo foram investigados os parasitos de três espécies de bivalves de interesse econômico (Crassostrea rhizophorae, Mytella guyanensis e Lucina pectinata) da Bahia. Foram analisados 540 exemplares, obtidos em duas coletas (agosto-2009 e fevereiro-2010), em três localidades. Os bivalves foram medidos quanto ao seu maior eixo, abertos e examinados macroscopicamente quanto à presença de parasitos ou sinais de enfermidades. Depois disso, foram fixados em solução de Davidson e processados por rotina de histologia, com inclusão em parafina e coloração com H\&E. O material foi examinado ao microscópio de luz. Nenhum parasito esteve associado a L. pectinata. Bactérias do tipo RLOs (organismos assemelhados a Rickettsia), Sphenophrya sp. (Ciliophora), Nematopsis sp. (Apicomplexa), Urastoma sp. (Turbellaria) e Bucephalus sp. (Digenea) foram observados tanto em C. rhizophorae quanto em M. guyanensis, sendo que a primeira apresentou ainda Ancistrocoma sp. (Ciliophora) e Tylocephalum sp. (Cestoda). Nematopsis sp. ocorreu em alta prevalência, porém, aparentemente, não causou danos aos bivalves. Bucephalus sp. causou destruição de tecidos, com castração, mas foi pouco prevalente. Os demais parasitos ocorreram em baixa prevalência e intensidade de infecçáo e sem causar danos.

Palavras-chave: Crassostrea rhizophorae, Lucina pectinata, Mytella guyanensis, patógenos, bivalves, parasitas.

\section{Introduction}

Many organisms can be found associated with bivalve mollusks, including viruses, bacteria, protists, fungi and metazoans (KINNE, 1983). Some of these symbionts can cause damage and sometimes disease in mollusks, thus affecting natural and farmed stocks.

\footnotetext{
*Corresponding author: Guisla Boehs

Departamento de Ciências Biológicas, Universidade Estadual de Santa Cruz - UESC,

Rod. Ilhéus-Itabuna, Km 16, CEP 45650-900, Ilhéus, BA, Brasil

e-mail: gboehs@uesc.br
}

Crassostrea rhizophorae (Guilding, 1828) (Ostreidae), Mytella guyanensis (Lamarck, 1819) (Mytilidae) and Lucina pectinata (Gmelin, 1791) (Lucinidae), all prominent species in the coastal mangroves of Bahia state, are economically important and are used for both local consumption and commercial sale in the region.

Crassostrea rhizophorae is already being cultivated on a small scale in Baía de Todos os Santos and in some areas of the southern coast of Bahia, as well as in Valença and Baía de Camamu. Despite 
the potential for cultivation of the two other species, they are still exploited only as extractive resources.

According to Rios (2009), the natural geographical distribution of C. rhizophorae covers the southern Caribbean, Venezuela, Suriname, Brazil and Uruguay; M. guyanensis is found from Mexico to Peru and from Venezuela to Brazil; and L. pectinata is distributed from North Carolina to Florida, Texas (USA), West Indies, Venezuela, Suriname and most of the coast of Brazil, from Amapá, in the north, to Santa Catarina, in the south. Crassostrea rhizophorae is known along the Brazilian coast as "ostra-do-mangue" (mangrove oyster), attached to hard substrates such as rocks and roots of the red mangrove Rhizophora mangle $\mathrm{L}$.. The other two species inhabit unconsolidated substrates (sandy-muddy sediments): $M$. guyanensis lives near mangrove roots, where it burrows just below the surface of the sediment; $L$. pectinata burrows more deeply, from 10 to $20 \mathrm{~cm}$.

Studies on parasites and diseases of mollusks are important since they provide the necessary knowledge for crop management and maintenance of natural resources. As reviewed by Boehs et al. (2012), on the Brazilian coast, the main records of pathogens in bivalve mollusks (e.g., Crassostrea rhizophorae, C. gigas, Perna perna, Mytella guyanensis, Anomalocardia brasiliana, Tagelus plebeius) include bacteria (e.g., Rickettsia-like organisms), protozoans (e.g., Sphenophrya sp., Trichodina sp., Ancistrocoma sp., Nematopsis sp., Perkinsus sp., Steinhausia mytilovum), unidentified fungi, and metazoans (e.g., Urastoma sp., Bucephalus margaritae, Tylocephalum sp., Polydora websteri, Pseudomyicola spinosus). Yet, these studies are still sparse, including in Bahia. The objective of this study was to catalogue the parasites of three economically important bivalve species (C. rhizophorae, $M$. guyanensis and L. pectinata) from the southern coast of Bahia, to generate knowledge both for managing natural stocks and for aquaculture activities (especially oyster farming) in the region.

\section{Materials and Methods}

Sampling was performed at three localities on the southern coast of Bahia: Camamu (13 $57^{\prime} \mathrm{S}$ and $\left.39^{\circ} 03^{\prime} \mathrm{W}\right)$, Valença (13 $28^{\circ} \mathrm{S}$ and $39^{\circ} 05^{\prime} \mathrm{W}$ ) and Canavieiras ( $15^{\circ} 44^{\prime} \mathrm{S}$ and $\left.38^{\circ} 55^{\prime} \mathrm{W}\right)$, in two sampling campaigns, one in August 2009 (winter) and the other in February 2010 (summer). At each locality, 30 specimens of each species were collected, totaling 180 from an overall total of 540 specimens. The collections were made manually, during low spring tide; oysters were collected from the mangrove roots with the aid of a knife. During each sampling, the temperature and salinity of adjacent waters were measured using a standard mercury thermometer and an Atago S/Mill manual refractometer, respectively. The specimens were brought to the Laboratory of Animal Histology (Universidade Estadual de Santa Cruz, UESC) in buckets, within a maximum period of six hours, and were immediately processed. The mollusks were washed under tap water and measured on their longest axis (anterioposterior $=$ length in L. pectinata, and dorsoventral = height in M. guyanensis and C. rhizophorae). Then, the specimens were opened with a knife and examined for the presence of parasites or anomalies seen with the naked eye; a cross-section of approximately $5 \mathrm{~mm}$ was cut with a scalpel and immersed in Davidson's fixative solution (SHAW; BATTLE, 1957) for 24 hours. The fixed tissues were processed using the routine histological technique, which included: dehydration in a graded ethanol series, diaphanization in xylene, paraffin embedding, and microtome sections of about $7 \mu \mathrm{m}$ in thickness. The sections were stained with Harris hematoxylin and eosin (H\&E) (HOWARD et al., 2004), and mounted under coverslips. Histological preparations were analyzed by light microscopy. After the parasites were identified and their site of infection was recorded, their prevalence was calculated as a function of the number of infected hosts divided by the number of hosts examined for a parasite species, according to Bush et al. (1997); the result was expressed as a percentage. All measurements are in micrometers. The Sørensen qualitative similarity index (ODUM, 1988) was used to compare the parasitic similarity between hosts and localities. In the case of one of the parasites, which occurred in high frequency in the samples, we used the Kruskal-Wallis test $(\alpha=0.05 \%)$ to compare the prevalence between localities and sample periods. The intensity of infection by parasites occupying large areas of tissue was calculated through the stereological technique proposed by Lowe et al. (1994), using a Weibel graticule. The tissue area occupied by parasites (PT) was evaluated at five locations of the infected animal's body, with subsequent calculation of the mean. Results were expressed in percentages. For parasites that showed low-level infections, a visual count of the number of parasites/ histological section was made. Minimum and maximum values are followed, in parentheses, by arithmetic means \pm standard deviation and the number of measured specimens.

\section{Results}

Water temperature ranged between 25 and $31.2^{\circ} \mathrm{C}$ at the three sampling localities, in the two periods, and the salinity ranged between 11 and 30\%o (Table 1).

There were no macroparasites or macroscopic signs of disease. Microscopic analyses revealed an absence of parasites in L. pectinata and the presence of bacteria, protozoa and metazoans in C. rhizophorae and M. guyanensis. Ancistrocoma sp. (Ciliophora: Ancistrocomidae) and Tylocephalum sp. (Cestoda: Lecanicephalidea: Tetragonocephalidae) were seen only in C. rhizophorae, while an unidentified metazoan was observed only in $M$. guyanensis. The two species also contained RLOs bacteria (Rickettsia-like

Table 1. Datas of temperature (T) and salinity (S) of the three study localities in August 2009 and February 2010, from the southern coast of Bahia State, Brazil.

\begin{tabular}{lccccccc}
\hline & \multicolumn{3}{c}{ Valença } & & Camamu & & Canavieiras \\
\cline { 2 - 7 } & T & S & T & S & T & S \\
\hline August 2009 & 25.5 & 11 & 27.5 & 29 & 25 & 15 \\
February 2010 & 30.1 & 29 & 31.2 & 29 & 30 & 30 \\
\hline
\end{tabular}


organisms), Sphenophrya sp. (Ciliophora: Sphenophryidae), Nematopsis sp. (Apicomplexa: Eugregarinida: Porosporidae), Urastoma sp. (Turbellaria: Urastomidae) and Bucephalus sp. (Digenea: Bucephalidae), resulting in a parasitic similarity of $77 \%$ between these bivalves. With the exception of Tylocephalum sp., which occurred only at Canavieiras, and an unidentified metazoan, occurring exclusively at Valença, the other parasites were recorded at all three localities; this resulted in $86 \%$ parasitic similarity between Valença and Canavieiras, and 92\% between these localities and Camamu. The parasitic similarity between sampling periods was $86 \%$.

Colonies of intracellular RLOs occurred in the epithelium of the digestive gland of C. rhizophorae and M. guyanensis (Figure 1a, b), the latter showing a prevalence of up to $30 \%$ at Canavieiras (Table 2). The diameter of colonies ranged from 6.6 to $20 \mu \mathrm{m}$ $(10.4 \pm 4.5 \mu \mathrm{m} ; \mathrm{n}=10)$ in C. rhizophorae and 9.5 to $21 \mu \mathrm{m}$ $(4.2 \pm 5.3 \mu \mathrm{m} ; \mathrm{n}=4)$ in $M$. guyanensis. The observed intensity of infection was 1.2 colonies/histological section in C. rhizophorae and 1-6 colonies/histological section in M. guyanensis. The RLOs led to localized hypertrophy and cell lysis.

The ciliate Sphenophrya sp. occurred in the gill epithelium of C. rhizophorae and $M$. guyanensis. This protist measured between 2 and $6 \mu \mathrm{m}$ in length in C. rhizophorae $(3.7 \pm 1.2 \mu \mathrm{m} ; \mathrm{n}=17)$ and between 1 and $6 \mu \mathrm{m}$ in $M$. guyanensis $(2.6 \pm 1.4 \mu \mathrm{m} ; \mathrm{n}=17)$; in both hosts, the ciliate had an oval shape and a basophilic nucleus. The parasite had a higher prevalence in C. rbizophorae (Table 2), where it induced xenoma formation (lesion arising from the proliferation of this protozoa, characterized by prominent hypertrophy of the host cell and its nucleus) in approximately $70 \%$ of cases. Xenomas were only recorded in collections performed in August, corresponding to late winter in the region. Xenomas were seen in both hosts an early stage of formation (Figure 1c), containing 2-3 ciliates, and an advanced stage, with about 70-80 ciliates/host cell (Figure 1d); however, the infection intensity was always very low: 1-2 xenomas/histological section. Apparently, damage was restricted to the infected cell.

The ciliate Ancistrocoma sp. was only observed in C. rhizophorae, in the lumen of its digestive tubules (Figure 1e), with prevalences up to $16.6 \%$ (Table 2). This oval-shaped protozoan had a mean length between 5 and $11 \mu \mathrm{m}(8.6 \pm 1.6 \mu \mathrm{m} ; \mathrm{n}=7)$, with a granular and basophilic macronucleus. The intensity of infection ranged from 1 to 6 ciliates/histological section.

Gregarine oocysts of Nematopsis were observed to infect hemocytes (Figure 1f) in both host species C. rhizophorae and $M$. guyanensis (prevalence was significantly higher in the former). There were no significant differences in the prevalence of parasites as a function of place and time. Oocysts in C. rhizophorae measured between 5.5 and $11 \mu \mathrm{m}(7.1 \pm 1.4 \mu \mathrm{m} ; \mathrm{n}=20)$ in length, and between 3 and $7 \mu \mathrm{m}(4.9 \pm 1.1 ; \mathrm{n}=20)$ in $M$. guyanensis. These parasites occurred mostly in the gills and mantle, and less often in the digestive gland of both hosts. In C. rhizophorae, they were also found in the adductor muscle, and in M. guyanensis in the foot. The number of oocysts/phagocyte was generally 1-3; however, in $C$. rhizophorae, there were up to 9 oocysts per phagocyte, and in $M$. guyanensis, up to 8 oocysts per phagocyte. Despite their conspicuous prevalence, especially in C. rhizophorae, the intensity of infection of these protists was moderate. The relative area occupied in the host tissue of C. rhizophorae was on average $9 \%$, and $7 \%$ in M. guyanensis. Tissue damage and hemocyte response were not observed.

The turbellarian Urastoma sp. was recorded between gill filaments (Figure 2a) of the two host species and also in the mantle cavity of $C$. rhizophorae. In this species, the turbellarian was found at all three sampling localities, with prevalence rates of up to $56.6 \%$ in August at Canavieiras (Table 2). The prevalence in M. guyanensis was lower (3.3\%), and this turbellarian was absent in mollusks from Valença (Table 2). The observed intensities for C. rhizophorae and M. guyanensis were 1-5, and 1-2 turbellarians/ histological section, respectively. This ectocommensal caused no apparent damage.

There was a low prevalence of Bucephalus sp. (Figure 2b) for C. rhizophorae and M. guyanensis at all three localities (Table 2). The parasite was observed at the sporocyst larval stage, when structures (sporocysts) consisted of germinative masses and cercariae. The trematode occurred in the mantle/gonad, digestive gland and gills. The method used to quantify the area occupied by the parasite ( $\mathrm{PT}=$ Parasite Tissue) in the host tissue (stereology) ranged from $32.3 \%$ to $39 \%$ in C. rhizophorae and $30.4 \%$ to $48.5 \%$ in $M$. guyanensis, which is considered a high level of infection according to Lowe et al. (1994) (classification stage III $=25-50 \%$ PT). One specimen of M. guyanensis showed 52.3\% PT, indicating very high infection intensity. There were no hemocyte responses; however, all infected specimens showed parasitic castration, with complete destruction of gametes and follicles and impossibility of sex determination; a single specimen of $M$. guyanensis showed a few follicles with vestiges of male gametes in some areas of the gonad.

A metacestode of Tylocephalum sp. was identified between the digestive-gland acini of a C. rhizophorae specimen from Canavieiras (Table 2). Around the metacestode, hemocyte infiltration was seen, clearly evidencing parasite-induced resorption (Figure 2c). There were two parasites/histological section.

A specimen of M. guyanensis collected in August at Valença showed an unidentified metazoan, perhaps a metacercaria, with only one parasite specimen per histological section in the gill filament. Hemocyte infiltration was observed around the parasite, but no tissue damage was apparent (Figure 2d; Table 2).

\section{Discussion}

The virtual absence of parasites in L. pectinata might be related to its location in the substrate, since this bivalve burrows approximately $20 \mathrm{~cm}$ below the surface of the sandy-muddy sediment of mangroves. According to Rios (2009), the conspicuous foot of bivalves of the family Lucinidae, which are tunnel builders, allows them to live in the deeper layers of the substrate (containing hydrogen sulfide and little or no oxygen), where other bivalve species can barely survive. Perhaps, these conditions may limit the establishment of parasites in L. pectinata. However, at least the digenean Bucephalus sp. has been observed in this species in another locality of the southern Bahia, in low prevalence (1.5\%) (OLIVEIRA, 2008).

The high similarity in parasitic fauna between C. rhizophorae and M. guyanensis, as well as that observed among different localities and 

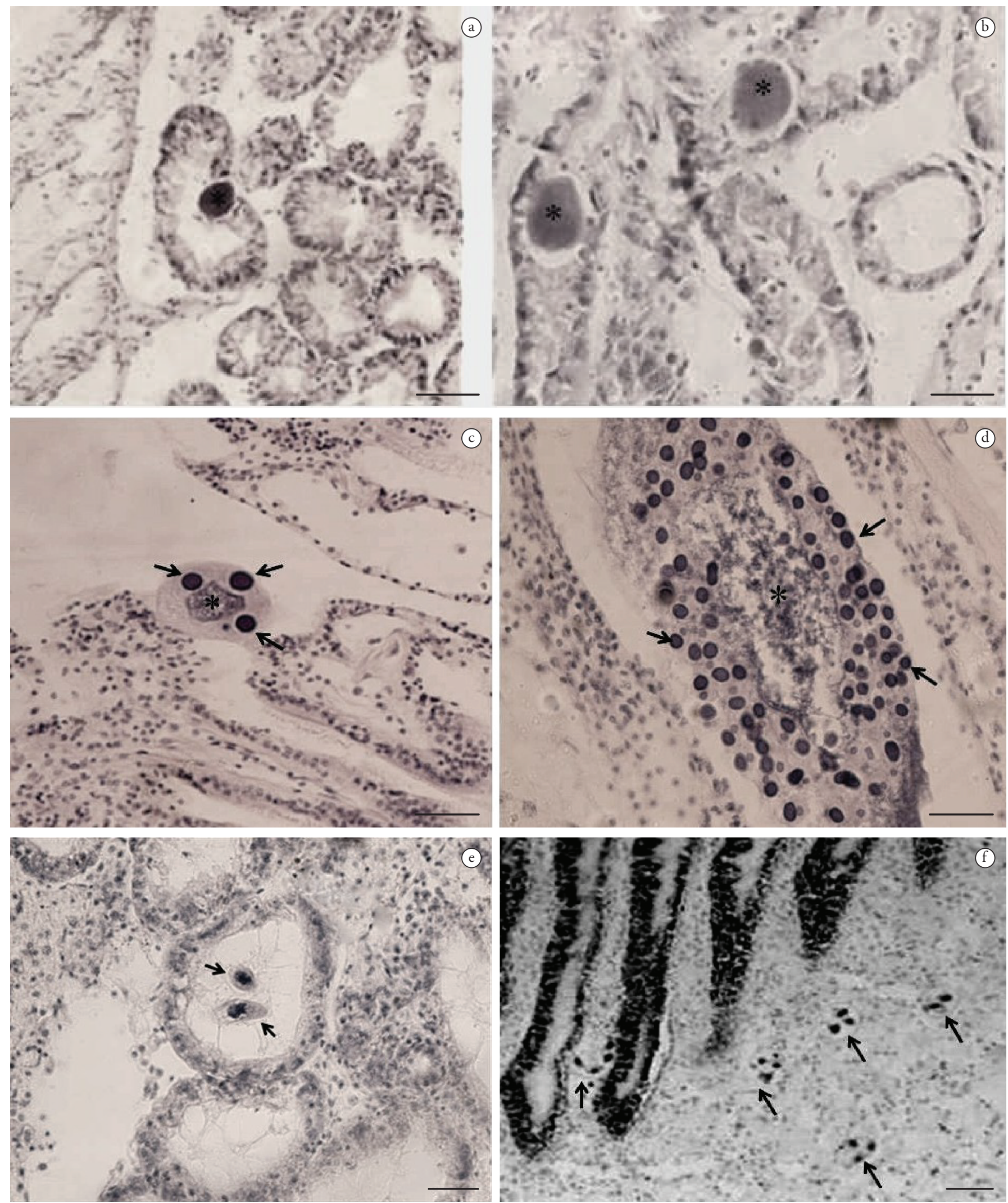

Figure 1. Parasites in two bivalves of economic interest from the south Bahia, Brazil. A-B. Intracellular colonies of Rickettsia-like organisms (RLOs) in the epithelium of digestive glands of a) Mytella guyanensis and b) Crassostrea rhizophorae. Bar $=20 \mu \mathrm{m}$; $\mathrm{c}$ ) Sphenophrya sp. in the gills of Crassostrea rhizophorae with xenoma formation, being c) in earlier and d) more advanced stage. Arrows = ciliates; $*=$ nucleus of the host cell. Bar $=20 \mu \mathrm{m}$; e) Ancistrocoma sp. in the lumen of digestive tubule of Crassostrea rhizophorae. Bar $=10 \mu \mathrm{m}$; f) Oocysts of the gregarine Nematopsis sp. in connective tissue of the gills of Crassostrea rhizophorae. Bar $=20 \mu \mathrm{m}$. 
Table 2. Parasites and their prevalences (\%) in two bivalves of economic interest of the coastal wetlands from the southern coast of Bahia State, Brazilcollected in August 2009 (A) and in February 2010 (F) ( $\mathrm{n}=60 /$ local).

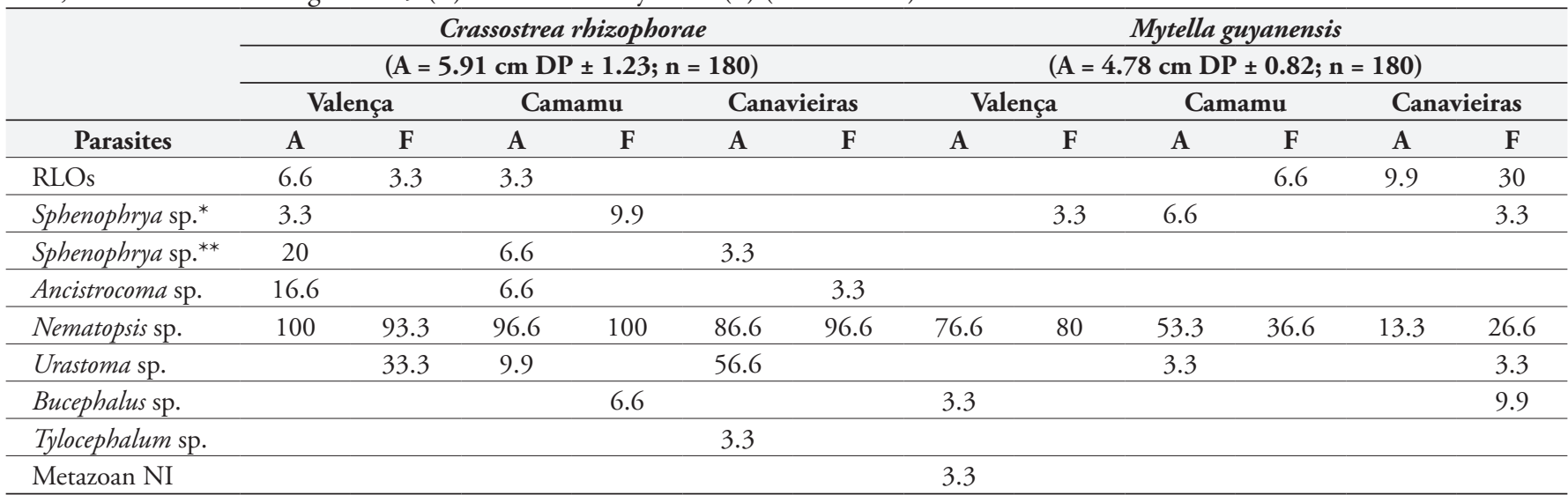

$\mathrm{A}=$ average height of specimens; RLOs = Rickettsia-like Organisms; Sphenophrya sp. ${ }^{*}$ without xenoma formation; Sphenophrya sp. ${ }^{* *}$ with xenoma formation; $\mathrm{NI}=$ not identified.


Figure 2. Metazoan in two bivalves of economic interest from south Bahia, Brazil. a) Urastoma sp. in gill of Crassostrea rhizophorae. Arrow = ocellus. Bar $=50 \mu \mathrm{m}$; b) Trematode sporocysts of Bucephalus sp. cointaining germ balls and cercariae (arrows) in mantle of Crassostrea rhizophorae. Bar $=20 \mu \mathrm{m}$; c) Tylocephalum sp. metacestode (arrows) in the connective tissue of the digestive gland of Crassostrea rhizophorae. ${ }^{*}=$ myzorhynchus. Bar $=50 \mu \mathrm{m}$; d) Unidentified metazoan in the gills of Mytella guyanensis. Bar $=20 \mu \mathrm{m}$. 
sample periods, were clearly shown in this study. With respect to the RLOs found in both species, the site of infection in the host (the digestive gland), the localized effect, and the absence of a hemocyte response converge with results from recent studies conducted by Da Silva et al. (2011) and Sabry et al. (2011) on C. rhizophorae and C. gigas (Thunberg, 1793) in Santa Catarina state, and by Boehs et al. (2010) and Ceuta and Boehs (2012) on M. guyanensis in Bahia state. Except for the study by Sabry et al. (2011), who identified prevalences of up to $30 \%$ for C. gigas (coinciding with the results of this study for $M$. guyanensis collected at Canavieiras, in February 2010), other studies have indicated a low prevalence of these bacteria. Other studies have also found a significant lack of damage, as seen in this study. Yet, Sabry et al. (2011), who observed RLOs in the stomach of one C. rhizophorae specimen, noted gastric-epithelium changes caused by these organisms.

Ciliates are commonly found in bivalves, but do not normally cause major damage to their hosts (BOWER et al., 1994). Regarding Ancistrocoma sp., the low infection intensity and the apparent lack of damage to the host are in line with previous observations of Sabry et al. (2011) on C. rhizophorae and C. gigas from Santa Catarina, but with prevalences of up to $40 \%$. As for Sphenophrya, according to Bower et al. (1994), these ciliates are found in a variety of bivalve species, in which they may cause xenoma. This lesion was previously observed by Boehs et al. (2009) for C. rhizophorae at Baía de Camamu. Other studies of Brazilian coastal mollusks have also reported the occurrence of Sphenophrya sp. in oysters, but without xenoma formation (NASCIMENTO et al., 1986; SABRY et al., 2011). In turn, in C. virginica (Gmelin, 1791), Winstead et al. (2004) observed xenoma formation in all oysters containing this protist. As observed in this study, the prevalence levels seen by these authors were low; still, the study conducted by Sabry et al. (2011) showed a prevalence of up to $70 \%$ for C. gigas, at one locality in Santa Catarina.

The high prevalence of the gregarine Nematopsis, especially in C. rhizophorae, is in line with several studies involving coastal bivalves from Brazil, such as on C. rhizophorae (SABRY et al., 2007, 2011; DA SILVA et al., 2011), M. guyanensis (PINTO; BOEHS, 2008; BOEHS et al., 2010; CEUTA; BOEHS, 2012), Anomalocardia brasiliana (Gmelin, 1791) (BOEHS et al., 2010) and Perna perna (Linnaeus, 1758) (DA SILVA et al., 2011). This study also confirmed that gills and mantle were the main organs affected by this parasite, although it may also occur in other anatomical regions such as the digestive gland and foot. Ceuta and Boehs (2012) also noted a high level of infection by Nematopsis sp. in the labial palps, and structural changes in these organs. This parasite is generally reported to cause little damage to bivalves, especially when the infection level is low (BOWER et al., 1994).

Among the observed platyhelminths, the turbellarian Urastoma has been reported to live in the gills, mantle cavity and digestive gland of several bivalves (LAUCKNER, 1983). In this study, Urastoma was found between the gill filaments of M. guyanensis and C. rhizophorae, as well as in the mantle cavity of the latter, where prevalence levels reached up to $56.6 \%$. In a study in southern Brazil, Sabry et al. (2011) reported a low prevalence of this turbellarian in the gill region of $C$. rhizophorae and $C$. gigas. Investigating the presence of $U$. cyprinae (Graff, 1882) in Mytilus galloprovincialis (Lamarck, 1819), in Galicia (Spain), Robledo et al. (1994) noted macroscopic lesions in the form of white spots. Through microscopic analysis, these authors also identified disorganization and compression of the gill filaments, hypertrophy of epithelial cells, and hemocyte infiltration, concluding that this ectocommensal causes significant changes in the feeding function. In southern Portugal, Francisco et al. (2010) also observed disorganization of the gill tissues and labial palps of the same host. The lack of apparent damage in this study was probably due to the low infestation intensity in both species.

Similarly to other Bucephalidae, the digenean Bucephalus spp. has a complex life cycle, using bivalve mollusks as intermediate hosts and some bony fishes as definitive hosts (LAUCKNER, 1983). These trematodes are so named due to their forked tail with a very short and wide base during the cercaria phase (WARDLE, 1990). Studies in some species of Mytilidae (LASIAK, 1993; BOEHS et al., 2010; CEUTA; BOEHS, 2012) have found macroscopic signs such as an orange color and/or fibrous appearance of the mantle, as indications of the presence of sporocysts, which could not be confirmed in this study. The prevalence levels usually below $10 \%$ corroborated the results from several studies involving Mytilidae on the Brazilian coast (DA SILVA et al., 2002, 2011; BOEHS et al., 2010;), the oyster C. rhizophorae from the Brazilian coast (NASCIMENTO et al., 1986), $C$. virginica from Florida, USA (WINSTEAD et al., 2004) and $M$. galloprovincialis from Portugal (FRANCISCO et al., 2010). All these studies confirmed tissue damage by Bucephalidae, especially in the gonads, characterizing parasitic castration. Castration was also caused by trematode sporocysts in Cerastoderma edule (Linnaeus, 1758) (Cardiidae) (CARBALLAL et al., 2001) and M. galloprovincialis (VILLALBA et al., 1997) in the region of Galicia. In this study, the observed infection level and lesions on the digestive gland and gills were smaller than those of the gonad. Despite the damage caused by infection, there was no apparent inflammatory response in the host. Contrary to what was seen in this study, Boehs et al. (2010) observed hemocyte infiltration around dead or degenerating sporocysts in $M$. guyanensis, while Da Silva et al. (2002) reported high hemocyte infiltration in heavily infected Perna perna. According to Bower (1992) and Carballal et al. (2001), high infection levels by sporocysts can reduce recruitment at the population level. To date, despite the obvious risk of Bucephalus spp. to its hosts, the low prevalence of this parasite does not appear to affect the natural populations of these bivalves on the southern coast of Bahia.

In Brazil, the metacestode Tylocephalum sp. has been reported to use different species of bivalves as an intermediate host (NASCIMENTO et al., 1986; BOEHS; MAGALHÁES, 2004; SABRY; MAGALHÃES, 2005; SABRY et al., 2007; BOEHS et al., 2010; DA SILVA et al., 2011; CEUTA; BOEHS, 2012). According to Lauckner (1983), this cestode completes its life cycle in elasmobranchs, and is more common in tropical and subtropical regions. Previous studies involving $C$. rhizophorae indicate the digestive gland as the major site of occurrence of this parasite (NASCIMENTO et al., 1986; SABRY; MAGALHÃES, 2005; SABRY et al., 2007); also, all studies showed encapsulation with intense hemocyte infiltration and in some cases, as in the present study, resorption. The same responses were observed in Tapes semidecussata Reeve, 1864 (Veneridae) (CHENG; RIFKIN, 1968) in Hawaii, and in C. virginica (WINSTEAD et al., 2004) in Florida. 


\section{Conclusion}

This study showed that, up to the present, natural populations of $C$. rhizophorae and $M$. guyanensis from the southern coast of Bahia are not seriously affected by the presence of parasites, since most of them were found in low prevalence; also, despite the high prevalence of Nematopsis sp., the intensity of infection was low. In spite of the obvious damage that Bucephalus sp. causes to tissues, the prevalence of this species was low.

\section{Acknowledgements}

The authors are thankful to the National Council for Scientific and Technological Development - CNPq (MCT-Brazil; ID 477317/2008-1) for financially aiding the project, to FAPESB, for granting a master's degree fellowship to the first author, and to $\mathrm{CNPq}$, for granting a scholarship for scientific initiation to the second author.

\section{References}

Boehs G, Lenz TM, Villalba A. Xenomas in Crassostrea rhizophorae (Ostreidae) from Camamu Bay, Bahia, Brazil. Braz J Biol2009; 69(2): 457-458. PMid:19675953. http://dx.doi.org/10.1590/ S1519-69842009000200032

Boehs G, Magalhães ARM. Simbiontes associados com Anomalocardia brasiliana (Gmelin) (Mollusca, Bivalvia, Veneridae) na Ilha de Santa Catarina e regiāo continental adjacente, Santa Catarina, Brasil. Rev Bras Zool 2004; 21(4): 865-869. http://dx.doi.org/10.1590/S010181752004000400021

Boehs G, Magalhães ARM, Sabry RC, Ceuta, LO. Parasitos e patologias de bivalves marinhos de importância econômica da costa brasileira. In: SilvaSouza AT, Lizama MLA, Takemoto R, organizadores. Patologia e Sanidade de Organismos Aquáticos. Maringá: ABRAPOA; 2012, p. 165-194.

Boehs G, Villalba A, Ceuta LO, Luz JR. Parasites of three commercially exploited bivalve mollusc species of the estuarine region of the Cachoeira river (Ilhéus, Bahia, Brazil). J Invertebr Pathol 2010; 103(1): 43-47. PMid:19850046. http://dx.doi.org/10.1016/j.jip.2009.10.008

Bower SM. Diseases and parasites of mussels. In: Gosling E. Developments in Aquaculture and Fisheries Science: The mussel Mytilus: Ecology, Physiology, Genetics and Culture (Dev Aquacult Fish Sci, 25). Amsterdam: Elsevier Science Publishers; 1992.

Bower SM, McGladdery SE, Price IM. Synopsis of infectious diseases and parasites of commercially exploited shellfish. Annu Rev Fish Dis 1994; 4(1): 1-199. http://dx.doi.org/10.1016/0959-8030(94)90028-0

Bush AO, Lafferty KD, Lotz JM, Shostak AW. Parasitology meets ecology on its own terms: Margolis et al. revisited. J Parasitol 1997; 83(4): 575-583. PMid:9267395. http://dx.doi.org/10.2307/3284227

Carballal MJ, Iglesias D, Santamarina J, Ferro-Soto B, Villalba A. Parasites and pathologic conditions of the cockle Cerastoderma edule populations of the Coast of Galicia (NW Spain). J Invertebr Pathol 2001; 78(1): 87-97. PMid:11812111. http://dx.doi.org/10.1006/jipa.2001.5049

Ceuta LO, Boehs G. Parasites of mangrove mussel Mytella guyanensis (Bivalvia: Mytilidae) of Camamu Bay, Bahia, Brazil. Braz J Biol 2012; 72(3): 421-427. PMid:22990810. http://dx.doi.org/10.1590/ S1519-69842012000300002
Cheng TC, Rifkin E. The occurrence and resorption of Tylocephalum metacestodes in the clam Tapes semidecussata. J Invertebr Pathol 1968; 10(1): 65-69. http://dx.doi.org/10.1016/00222011(68)90264-4

Da Silva PM, Magalhães ARM, Barracco MA. Pathologies in commercial bivalve species from Santa Catarina State, southern Brazil. J Mar Biol Assoc UK 2011; 92(3): 571-579. http://dx.doi.org/10.1017/ S0025315411001007

Da Silva PM, Magalhães ARM, Barracco MA. Effects of Bucephalus sp. (Trematoda: Bucephalidae) on Perna perna mussels from a culture station in Ratones Grande Island, Brazil. J Invertebr Pathol 2002; 79(3): 154-162. http://dx.doi.org/10.1016/S00222011(02)00026-5

Francisco CJ, Hermida MA, Santos MJ. Parasites and symbionts from Mytilus galloprovincialis (Lamarck, 1819) (Bivalves: Mytilidae) of the Aveiro Estuary Portugal. J Parasitol 2010; 96(1): 200-205. PMid:19785477. http://dx.doi.org/10.1645/GE-2064.1

Howard DW, Lewis EJ, Keller BJ, Smith CS. Histological techniques for marine bivalve mollusks and crustaceans. NOAA Technical Memorandum NCCOS 2004; 5(1): 1-218.

Kinne O. Diseases of Marine Animals. Hamburg: Biologische Anstalt Helgoland; 1983.

Lasiak TA. Bucephalid trematode infections in the brown mussel Perna perna (Bivalvia: Mytilidae). Afr J Mar Sci 1993; 13(1): 127-134. 1993.

Lauckner G. Diseases of Mollusca: Bivalvia. In: Kinne O. Diseases of Marine Animals. Hamburg: Biologische Anstalt Helgoland; 1983. p. 477-970.

Lowe DM, Salkeld PN, Carr MR. The effect of geographical location on the cellular composition of the mantle tissue of the mussel, Mytilus edulis. J Mar Biol Assoc UK 1994; 74(1): 225-232. http://dx.doi. org/10.1017/S0025315400035785

Nascimento IA, Smith DH, Kern II F, Pereira SA. Pathological findings in Crassostrea rhizophorae from Todos os Santos Bay, Bahia, Brazil. J Invertebr Pathol 1986; 47(3): 340-349. http://dx.doi. org/10.1016/0022-2011(86)90105-9

Odum EP. Ecologia. Rio de Janeiro: Guanabara Koogan; 1988.

Oliveira, JB. Parasitos associados à lambreta Lucina pectinata (Gmelin, 1791) (Mollusca: Bivalvia) na região estuarina do Rio Cachoeira (Ilhéus, Bahia) [Monografia]. Ilhéus: Universidade Estadual de Santa Cruz; 2008. Disponível na Biblioteca Central da UESC.

Pinto TR, Boehs G. Nematopsis sp. (Apicomplexa: Eugregarinida) em Mytella guyanensis (Lamarck, 1819) (Bivalvia: Mytilidae) da região estuarina do Rio Cachoeira, Ilhéus, Bahia, Brasil. Braz J Vet Res Anim Sci 2008; 45(2): 95-100.

Rios E. Compendium of Brazilian Sea shells. Rio Grande: Evangraf; 2009.

Robledo JAF, Cáceres-Martínez J, Sluys R, Figueras A The parasitic turbellarian Urastoma cyprinae (Platyhelminthes: Urastomidae) from blue mussel Mytilus galloprovincialis in Spain: occurrence and pathology. Dis Aquat Org 1994; 18(1): 203-210. http://dx.doi.org/10.3354/ dao018203

Sabry RC, Da Silva PM, Gesteira TCV, Pontinha VA, Magalhães ARM. Pathological study of oysters Crassostrea gigas from culture and C. rhizophorae from natural stock of Santa Catarina Island, SC, Brazil. Aquaculture 2011; 320(1-2): 43-50. http://dx.doi.org/10.1016/j. aquaculture.2011.08.006 
Sabry RC, Gesteira TCV, Boehs G. First record of parasitism in the mangrove oyster Crassostrea rhizophorae (Bivalvia: Ostreidae) at Jaguaribe River estuary - Ceará, Brazil. Braz J Biol 2007; 67(4): 755-758. PMid:18278331. http://dx.doi.org/10.1590/S1519-69842007000400024

Sabry RC, Magalhães ARM. Parasitas em ostras de cultivo (Crassostrea rhizophorae e Crassostrea gigas) da Ponta do Sambaqui, Florianópolis, SC. Arq Bras Med Vet Zootec 2005; 57(S2): 194-203.

Shaw BL, Battle HI. The gross and microscopic anatomy of the digestive tract of the oyster Crassostrea virginica (Gmelin). Can J Zool 1957; 35(1): 325-347. http://dx.doi.org/10.1139/z57-026
Villalba A, Mourelle SG, Carballal MJ, López C. Symbionts and diseases of farmed mussels Mytilus galloprovincialis throughout the culture process in the Rías of Galicia (NW Spain). Dis Aquat Org 1997; 31(2): 127-139. http://dx.doi.org/10.3354/dao031127

Wardle WJ. Larval Bucephalids (Trematoda: Digenea) parasitizing bivalve molluscs in the Galveston Bay Area, Texas. J Helminthol Soc Wash 1990; 57(1): 5-11.

Winstead JT, Volety AK, Tolley SG. Parasitic and symbiotic fauna in oysters (Crassostrea virginica) collected from the Caloosahatchee River and estuary in Florida. J Shellfish Res 2004; 23(3): 831-840. 